Providence College

DigitalCommons@Providence

4-2010

\title{
Vicarious Revolutionaries: Martial Discourse and the Origins of Mass Party Competition in the United States, 1789-1848
}

Cedric De Leon

Providence College, cdeleon@providence.edu

Follow this and additional works at: https://digitalcommons.providence.edu/sociology_fac

Part of the Political Science Commons

De Leon, Cedric, "Vicarious Revolutionaries: Martial Discourse and the Origins of Mass Party Competition in the United States, 1789-1848" (2010). Sociology Department Faculty Publications. 2.

https://digitalcommons.providence.edu/sociology_fac/2

This Article is brought to you for free and open access by the Sociology at DigitalCommons@Providence. It has been accepted for inclusion in Sociology Department Faculty Publications by an authorized administrator of DigitalCommons@Providence.For more information, please contact dps@providence.edu. 


\title{
Vicarious Revolutionaries: Martial Discourse and the Origins of Mass Party Competition in the United States, 1789-1848
}

\section{Cedric de Leon, Assistant Professor of Sociology Providence College}

\begin{abstract}
Social scientists of democratic change have emphasized the role of class action in that process, neglecting the discursive shift that was necessary to legitimate mass party competition in the early American case. Although historians of U.S. party formation have emphasized the discursive dimension of this transition, they have focused on more formal theories of party and neglected the importance of martial discourse, which was perhaps more pedestrian, but had a distinctive mass appeal. Drawing on the papers of prominent politicians and the editorials of local party newspapers in Alabama and Illinois, I argue that incipient party elites used the language of wartime discipline to recruit national-level leaders, local operatives, and voters to the new form of elective politics. Martial discourse was therefore integral to the larger discourse of party, which ultimately helped to overcome the inherited antipartyism of the early Republic.
\end{abstract}

This paper centers on a paradox of early American democratization, namely that as mass party competition got under way, political elites ${ }^{1}$ mixed party practices with antiparty rhetoric. In one sense, the intolerance of partisanship is not at all surprising.

Many thanks to all those who read previous drafts of this piece: Mills Thornton, Julia Adams, Howard Kimeldorf, Mark Mizruchi, Daniel Klinghard, Mark Hyde, Bob Trudeau, Claire Decoteau, Emily Heaphy, Dan Carpenter, and Gerry Leonard. John Quist helped me navigate the Tuscaloosa archives. Mills Thornton has been my guide through the complex terrain of antebellum political history. I would also like to thank Ed Bridges at the Alabama Department of Archives and History; John Hoffman at the University of Illinois Library; Jessica Lacher-Feldman, Clark E. Center, Jr., and Kevin Ray at the Hoole Special Collections Library at the University of Alabama; and Lesley Martin, Debbie Vaughan, and AnneMarie Chase at the Chicago Historical Society. Please direct all correspondence to Cedric de Leon at cdeleon@providence.edu, 1 Cunningham Square, Providence College, Providence, RI 02918.

1. I use the term "elite" to refer to politicians. I use the term "class" to refer to economic groups. Post-revolutionary politicians were not the landed and urban elite often referred to in the democratization literature. A key feature of post-revolutionary politics was the election to state legislatures of men of moderate wealth who replaced the wealthy few as the dominant force in American politics. See Jackson Turner Main, "Government by the People: The American Revolution and the Democratization of the Legislatures," William and Mary Quarterly 23 (1966): 404-406 and Gordon S. Wood, The Radicalism of the American Revolution (New York: Vintage, 1992), 87.
As Barry Schwartz observes, early America "stressed the republican virtues of obligation, sacrifice, and disinterestedness" and accordingly reserved the terms "party" and "faction" for any unpatriotic group that placed private interests ahead of the public good. For example, because "revolutionary republicans took political economy, citizenship and faction to be inextricably bound together," among the more hated parties were elusive "aristocrats" who schemed to monopolize the Republic's wealth, rather than "promote widespread landownership as the foundation of republican citizenship."

However, the pervasiveness of antipartyism bears further analysis because the practitioners of antiparty rhetoric were also prominent party leaders like Martin Van Buren and his compatriots in New York state's "Albany Regency," the nucleus of the incipient Democratic organization. The puzzle that guides this paper, therefore, is the following: how could mass party competition originate in the interplay of partisanship on the one hand and antipartyism on the other?

2. Barry Schwartz, George Washington: the Making of an American Symbol (New York: Free Press, 1987), 193; Marc W. Kruman, "The Second American Party System and the Transformation of Revolutionary Republicanism," Journal of the Early Republic 12 (1992): 511-512. 
Drawing on the papers of national elites and on early nineteenth century Alabama and Illinois party newspapers, I argue that this rhetorical mix was an important part of a larger discursive shift that overcame the inherited antipartyism of the early Republic and thus eased the transition to mass party competition. The first party system (1789-1827), like the second (1828-1860), was rife with interelite conflict, but the former was different in at least two respects. The political elites of the first party system did not see themselves as "parties" but as loose coalitions and used the terms "party" and "faction" to stigmatize their political adversaries. Second, and as a result, the first party system lacked an effective institutional mechanism for managing dissent peacefully. The constitutional phase of democratization had introduced a contradiction into the heart of American government by, on the one hand, furnishing political elites with new resources with which to compete (voters), and on the other hand, opening up elites to public challenge and thus to reoccurring crises of legitimacy. ${ }^{3}$ In order to discipline and capitalize on the expanding franchise without resorting to state violence, political elites had to simultaneously develop institutional structures of party command that could mobilize large numbers of people and also legitimate the existence of an organizational form (parties), which had previously been seen as illegitimate.

The elites of the second party system, I argue, met these demands in part by framing the political struggles of the day as high stakes matters akin to the revolution. ${ }^{4}$ Because the revolution was imagined simultaneously as a conflict between British and patriot forces as well as a triumph of patriotic solidarity, the politicians of the second party system deployed partisan (that is, oppositional) and antipartyist (that is, unifying) themes in political contests. The rhetorical invocation of wartime discipline elevated political parties to the status of the revolutionary militia itself, and consequently, the term, party, came to denote a defense against, rather than a source of, corrupt selfinterest. The military form therefore did what other arguments for party discipline could not do.

Unlike other partyist discursive currents, which were more formal and legalistic in character, martial discourse had mass appeal. It could connect national elites with local operatives and voters on the ground by offering a new generation of Americans a chance to become soldiers in a revolution that they were

3. By 1825 , prior to the advent of the mass party system, "every state but Rhode Island, Virginia, and Louisiana had achieved universal manhood suffrage." Wood, Radicalism of the American Revolution, 294. For a comprehensive account of the broadening franchise in this period, see Alexander Keyssar, The Right to Vote: The Contested History of Democracy in the United States (New York: Basic Books, 2000).

4. By discourse, I mean a species of talk whose logic legitimates some practices and disqualifies others within a given polity. simply too young to fight. That is, if the partyist theory of Van Buren and others provided the intellectual rationale for the mass party system, then martial discourse provided its emotional content and thus worked to "recruit" Americans at all levels to participate in a new form of elective politics. In doing so, martial discourse also helped to preclude reoccurring crises of elite legitimacy for a generation.

By addressing the problem of early American democratization in this way, this paper contributes to both the social science and historiographical literatures on the subject. Historians have long known and written about the party-antiparty paradox, but social scientists have yet to incorporate its implications for the study of democratization. ${ }^{5}$ Most of this literature suggests that democratic change originates in the presence and relative strength of competing class actors. In contrast, I argue that at least one critical phase of democratization-the advent of mass party competition-is facilitated by the manipulation and deployment of discourses by political elites. In addition, although historians have documented the discursive dimensions of this transition, they have largely focused on the formal theories of party. In this paper, I combine the otherwise isolated literatures on martial discourse and antipartyism to offer a new synthesis, namely that while rational argument undoubtedly worked to overcome antipartyism, martial discourse played a complementary role in this transition by furnishing a language of mobilization that could recruit diverse sets of actors to the practice of mass party politics.

\section{POLITICAL PARTIES AND DEMOCRATIZATION}

E. E. Schattschneider once argued, "Political parties created democracy ... modern democracy is unthinkable save in terms of the parties." Indeed, it was the centrality of party competition to democracy that animated V. O. Key's classic critique of the Solid South's one-party system. "The best government," he wrote,

5 . The key texts on the party-antiparty paradox include Lynn L. Marshall, "The Strange Stillbirth of the Whig Party" American Historical Review 72 (1967): 445-468; Michael Wallace, "Changing Concepts of Party in the United States: New York, 1815-1828," American Historical Review 74 (1968): 453-491; Richard Hofstadter, The Idea of a Party System: The Rise of Legitimate Opposition in the United States, 1780-1840 (Berkeley and Los Angeles: University of California Press, 1969); Major Wilson, "Republicanism and the Idea of Party in the Jacksonian Period," Journal of the Early Republic 8: 419-442; Kruman, "The Second American Party System"; David Waldstreicher, In the Midst of Perpetual Fetes: The Making of American Nationalism, 1776-1820 (Chapel Hill: University of North Carolina Press, 1997); Ronald P. Formisano, "The 'Party Period' Revisited," Journal of American History 86 (1999): 93-120; Mark Voss-Hubbard, "The 'Third Party Tradition' Reconsidered: Third Parties and American Public Life, 1830-1900," Journal of American History 86 (1999): 121-150; Gerald Leonard, The Invention of Party Politics: Federalism, Popular Sovereignty, and Constitutional Development in Jacksonian Illinois (Chapel Hill: University of North Carolina Press, 2002). 
"results when there is free and vigorous competition at the ballot box in contests in which genuine issues are defined and candidates take a stand." Robert Dahl, whose foundational work on polyarchy remains a touchstone for defining what we mean when we speak of formally existing democracy, similarly defines polyarchies as "highly inclusive and extensively open to public contestation." That is, to qualify as a polyarchy, it is insufficient to enfranchise the mass public; a regime must allow legal opposition, which, in most known cases of polyarchy, has taken the form of a competitive mass party system. ${ }^{6}$

Despite the known links between political parties and democracy, the key controversy in the literature on democratic transitions and expansions has centered on which economic class-landowning, bourgeois, peasant, or working-is the prime mover of democratic change. In this, there are two orienting poles: those who privilege the upper classes in that process and those who privilege the lower classes. The canonical example of the upper-class-driven view is Barrington Moore's claim that "a vigorous and independent class of town dwellers has been an indispensable element in the growth of parliamentary democracy. No bourgeois, no democracy."7 In contrast, Rueschemeyer et al. find that when landed classes and the bourgeoisie "felt acutely threatened in their vital interests by popular pressures, they invariably opposed democracy," leading them to suggest that in fact "the working class was the most consistently pro-democratic force." ${ }^{8}$ The upper-/ lower-class divide, in turn, has given rise to attempts at synthesis. Collier, for example, offers "an institutional and path-dependent explanation" in which labor's participation in democratization varies with "the context of prior experience with democratic regimes and the type of antecedent regime." Accordingly, Collier finds several patterns of democratization,

6. E. E. Schattschneider, Party Government (New York: Holt, Rinehart and Winston, 1942), 1; V. O. Key, Southern Politics (New York: Vintage, 1949), x; Robert A. Dahl, Polyarchy: Participation and Opposition (New Haven and London: Yale University Press, 1971), 8. For others who employ Dahl's assumptions, see, for instance, Guillermo O'Donnell and Philippe C. Schmitter, Transitions from Authoritarian Rule: Tentative Conclusions about Uncertain Democracies (Baltimore and London: Johns Hopkins University Press, 1986), 74n2 and Dietrich Rueschemeyer, Evelyne Huber Stephens, and John D. Stephens, Capitalist Development and Democracy (Cambridge, UK: Polity Press, 1992), 10, 314n5.

7. Barrington Moore, Jr., Social Origins of Dictatorship and Democracy: Lord and Peasant in the Making of the Modern World (Boston: Beacon Press, 1966), 418. For other elite-driven approaches, see also O'Donnell and Schmitter, Transitions from Authoritarian Rule; Terry Lynn Karl, "Dilemmas of Democratization in Latin America," Comparative Politics 23 (1990): 1-21; and John Peeler, Building Democracy in Latin America (Boulder, CO: Lynne Rienner Publishers, 1998).

8. Rueschemeyer et al., Capitalist Development and Democracy, 8. For another non-elite-driven approach, see also Göran Therborn, "The Travail of Latin American Democracy," New Left Review 113114 (1979): 80, 85 . some of which are upper-class-driven, others workingclass-driven, and still others "joint projects." 9

This overarching class emphasis has led scholars of democratization, first, to cut across otherwise robust theoretical insights on parties too quickly; second, to settle on an approach to parties that defines their role too narrowly; and third, to assume the legitimacy of parties prematurely. Rueschemeyer and the Stephenses, for example, view party elites as middlemen who regulate the perceived threat posed by the working class to the dominant classes in transitions to democracy. "Political parties," they find, "emerged in the crucial role as mediators," tempering the radicalism of the lower classes so as to keep the bourgeoisie from pursuing authoritarian alternatives. Although the "party-as-mediator" approach uncovers some of what party elites do in democratic transition, Rueschemeyer et al. actually offer a potentially broader conceptualization of party practices late in their conclusion, one that treats politics "as a distinct analytical dimension of civil society which is strongly affected by but cannot be reduced to the economic and class structure." 10

Rather than make "an attempt ... to explain the origins of party systems," however, they then quickly cede their ground to exactly the opposite theory of Lipset and Rokkan, in which parties are relegated to the role of expressing the demands of cleavage groups. ${ }^{11}$ The American case involves some mediation to the degree that effective disciplinary rhetoric may well have kept certain sectors of society from abandoning the democratic project in favor of more repressive alternatives. Nevertheless, this arrangement does not emerge in the context of mediation between an upper and a lower class but in a struggle between two factions of the second generation political elite. Nor is the language of this struggle one of mediation but of violent insurrection, channeled into the ritual of mass party competition. Finally, the party-as-mediator framework unduly assumes a) the legitimacy of parties as an organizational form and b) the authority of parties to mediate on behalf of competing class actors. In sum, Rueschemeyer et al., like other scholars of democratization, conceive of party elites in ways that

9. Ruth Berins Collier, Paths toward Democracy: the Working Class and Elites in Western Europe and South America (New York: Cambridge University Press, 1999). For other synthetic approaches, see also Peter Winn, Weavers of Revolution: The Yarur Workers and Chile's Road to Socialism (New York: Oxford University Press, 1986) and Jeffery M. Paige, Coffee and Power: Revolution and the Rise of Democracy in Central America (Cambridge and London: Harvard University Press, 1997). 287.

10. Rueschemeyer et al., Capitalist Development and Democracy, 9 ,

11. Rueschemeyer et al., Capitalist Development and Democracy, 288; Seymour Martin Lipset and Stein Rokkan, Party Systems and Voter Alignments: Cross-national Perspectives (New York: Free Press, 1967). 
exclude the cultural dimensions of political practice and thereby fall short of explaining how mass party politics become legitimate in the first place.

Like Rueschemeyer et al., others in the field have made important observations about the discursive dynamics of democratic transition only to retreat to more familiar ground. Paige, for example, explains Central America's recent transition to neoliberal democracy in terms of the convergence of liberal and socialist discourses but then concludes by giving most of the credit to a "socialist revolution from below." Similarly, O'Donnell and Schmitter make the provocative claim that "the key to the party's efficacy ... lies in its capacity to generate symbols of partial political identity ... which bring together voters and militants across many of the lines which otherwise divide them." However, in a return to the rational choice basis of their "elite bargaining" approach, the two ultimately confine the role of party elites to a single moment in democratic transition, the "founding election," in which a "cartel of party elites" are said to forge "pacts" that "(1) limit the agenda of policy choice, (2) share proportionately in the distribution of benefits, and (3) restrict the participation of outsiders in decision-making."12

Inattention to political discourse also renders the social science literature on party formation ill-equipped to explain how second party system elites overcame the inherited antipartyism of the early national electorate. John Aldrich holds that American political parties emerged first as legislative coalitions, and then as mass parties, to solve successive collective action problems. Thus, "primarily parties-in-government" surfaced when legislators discovered that their preferences could be realized more efficiently when they aligned themselves with likeminded colleagues. "A series of problems that necessarily arise in elections and in governance," he writes, "make it possible for politicians to win more of what they seek to win, more often, and over a longer period by creating political parties." Incipient Democratic Party elites like Martin Van Buren then confronted the free rider problems associated with organizing largely autonomous state elites and a far-flung mass electorate by building the National Alliance and Caucus, which worked in tandem to reduce the costs and maximize the perceived benefits and intrinsic value of mass party affiliation. ${ }^{13}$

Another elite-driven approach argues that patronage systems are the prime mover of mass party formation. According to Shefter (1994) elites use parties as vehicles to mobilize mass constituencies either to take, or to secure their hold, over the

12. Paige, Coffee and Power, O'Donnell and Schmitter, Transitions from Authoritarian Rule, 40-41, 57-58.

13. John H. Aldrich, Why Parties?: the Origin and Transformation of Political Parties in America (Chicago: University of Chicago Press, 1995), 28, 47-50, 97, 100-125. government. At the core of the mass party system, then, is the mechanism of calculated mutual benefit: parties distribute "divisible benefits" to individuals for their political support or collective benefits "to elicit contributions of money, labor, or votes."14

In contrast, Lipset and Rokkan's view of party formation holds that parties "have an expressive function" and "develop a rhetoric for the translation of contrasts in the social and cultural structure into demands for action." Parties reflect the true motor of politics, social differentiation (for example, along class or religious lines), in the legislative sphere. Moreover, cleavages are said to originate in far off "critical junctures" like the Protestant Reformation and Industrial Revolution, such that most political elites often have no temporal access to the historic rifts that supposedly divide their communities. ${ }^{15}$

The shortcomings of these approaches to party formation mirror those of the democratization literature. First, they assume away the cultural impediments to party formation. For Aldrich, the key challenges to mass party formation were the collective action problems inherent to the organization of rational actors, not the discursive legitimation of political parties as an organizational form. Shefter's approach presupposes that party patronage will be seen as a legitimate practice, presumably because individuals and groups stand to benefit from its enactment. Lipset and Rokkan assume that critical junctures beget new social cleavages and that new social cleavages naturally beget new parties, which represent those competing interests. None of these approaches contemplates a political culture within which parties are so stigmatized that elites would first have to reinvent parties in order to inaugurate mass party competition. Second, the agency of political elites is theorized too narrowly. Lipset and Rokkan in particular only allow politicians to translate ancient social divides into demands for action. Aldrich is better on this score, but for him, and indeed for Shefter, elite agency amounts to rational calculation. There is potential for something more in Aldrich's account of the transition from legislative to mass parties because he views the intrinsic value of voting ("citizen duty" or "being known to be on the right side") as part of the calculus of the early mass

14. Martin Shefter, Political Parties and the State: The American Historical Experience (Princeton: Princeton University Press, 1994), $5,21$.

15. Lipset and Rokkan, Party Systems and Voter Alignments, 5; Stein Rokkan, State Formation, Nation-building, and Mass politics in Europe: the Theory of Stein Rokkan (Cambridge: Cambridge University Press, 1999), 302-305. Duverger and the institutional school represent a fourth approach that focuses on the importance of electoral rules in shaping the character of party systems. Maurice Duverger, Political Parties: Their Organization and Activity in the Modern State (London: Methuen, 1954). However, institutionalists are silent on the origins of parties per se. They are better at addressing what kind of parties and how many parties. 
electorate. One might therefore plausibly frame martial discourse as one among a complex of factors that counter the costs of mass party affiliation. However, Aldrich's focus is not on the rhetoric driving mass mobilization but the self-interest of elites, who above all understood that "control of a majority in the public brought control of office, and with that, control of policy and the spoils of office." 16

Even if none of these criticisms held water, however, most of these theories would suffer from the problem of timing. The central controversy in the democratization literature turns on which social class is the most consistent bearer of democratic change, yet as Jackson Turner Main demonstrated long ago, many first and second party system elites were drawn from similar social strata, a fact that gives us little purchase in explaining the differences between the first and second party systems. Lipset and Rokkan hold that social cleavages give rise to new party systems, yet the regional, ethnocultural, and socioeconomic cleavages that divided the first party system also operated in the second. Finally, although the spoils system has become synonymous with the Jackonian Democratic Party, patronage was also part of the first party system's landscape, as in the case of John Adams's infamous "midnight appointments." There is sufficient doubt, therefore, that these approaches can explain why the first party system suffered from reoccurring crises of elite legitimacy, whereas the second party system did not. Elements of martial discourse had existed in the first party system, but second generation elites would first have to distort and reconstitute them before they could be of service in making the practice of mass partisanship palatable to an otherwise antiparty republic. Of the foregoing hypotheses, then, only martial discourse has the promise of explaining this transition in ways that others cannot and that impart new perspective to our understanding of party development and democratization in the early United States.

\section{THE HISTORIOGRAPHY OF ANTIPARTYISM AND MARTIAL DISCOURSE}

Scholars of American political history have had a long and extensive engagement with the party-antiparty paradox, and unlike scholars of democratization in the social sciences, they have focused their attention squarely on the discursive shift that gave rise to the mass party system. In that sense, historians are innocent of the theoretical problems enumerated thus far. Instead, the historiographical literature is limited in two other ways. First, the particular aspects of partyist discourse emphasized by the literature lack a mass appeal that could mobilize actors at all levels of the body politic. Second, historians of

16. Aldrich, Why Parties?, 100-102. party have not engaged either with the evidence of martial discourse in their own work or with the literatures that make some effort to explain martial discourse.

The historiography has focused largely on the origins and subsequent evolution of party theory. Hofstadter, for instance, traces the rise and fall of successive schools of thought, from the more uncompromising antipartyism of Bolingbroke and Hamilton, to the Hume-Madison synthesis, which saw parties as an inevitability that must be controlled by institutional checks, and at last to Martin Van Buren and the Albany Regency who "demanded not merely voluntary concurrence" among their colleagues as their pro-party precursor, Edmund Burke, had thought sufficient, "but thoroughgoing subordination." Similarly, Wilson held that the "defensive prerogative" of the country to form a party in the face of a conspiracy by the kingly court was originally Bolingbroke's formulation and later informed Van Buren's theory of party. Thus, Wilson wrote, "Van Buren took the Bolingbroke rationale for temporary party activity by the Country and turned it into an argument for permanent organization." Most recently, Leonard has explained the emergence of mass party politics in terms of successive forms of constitutionalism. That account begins with Madison's "Constitution against parties," continues with the rise of Van Buren constitutionalism, which justified party formation by insisting "the proposed party was to be a party of the whole sovereign democracy," as opposed to "selfinterested minorities" or "aristocrats," and ends with the unexpected triumph of "the two-party constitution." 17

The decisiveness of formal theories of party in overcoming the inherited antipartyism of the early Republic is now hardly in doubt, but the more pedestrian and perhaps less scholarly discourse of wartime discipline seems to have escaped the attention of historians of party. This paper aims to fill that gap. Martial discourse was no more important than the theories that underpinned the emergence of mass party politics, but it helped to frame partisanship in ways that diverse sets of actors could understand and accept, and it acted as a rhetorical device for the recruitment of these actors into the new form of elective politics. Martial discourse, in other words, complemented the theoretical basis of party discourse. For example, the solidaristic and oppositional strains of martial discourse meshed with the contrast between the indivisible democracy and the minoritarian aristocracy, which was at the core of what Leonard calls the partyist constitution. Thus, while the Van Burenite avant-garde in Illinois no doubt advanced

17. Hofstadter, The Idea of a Party System, 16, 18-23, 24, 252; Wilson, "Republicanism and the Idea of Party," 433; Leonard, Invention of Party Politics, 9, 11, 17. 
their theories in straightforward constitutional terms as Leonard convincingly shows, they also, I maintain, simultaneously deployed martial discourse as if to translate the party and antiparty pillars of Van Buren constitutionalism into a language of mass mobilization that could hail national elites, local operatives, and rank-and-file voters to action.

This is not to suggest that martial discourse is terra incognita. The historiography of early American politics is littered with martial quotations from antebellum sources, but many historians appear unaware or uninterested in the specifically martial content of their evidence. For example, in one of the foundational essays on mass party formation, Michael Wallace quoted this passage from the National Advocate: "We will surrender nothing voluntarily to our opponents; let them fight and conquer, as the democratic party has done, and we will submit quietly." The passage is classically martial. The words, "surrender," "fight," "conquer," and "submit," spring from the page, but rather than explore the implications of martial discourse for the partisan turn, Wallacelike other historians of party-uses this quotation as evidence of something else, namely the majoritarian logic of Van Buren's theory of party. ${ }^{18}$

A handful of historians have published on martial discourse, though typically not in reference to early mass party formation. Richard Jensen, for example, documents the transition from an older "army style" of political language to a new "merchandising style" in the 1890s. Jean Baker has explored martial discourse as one among several important elements of northern Democratic Party political culture and has argued, in another context, that it was critical to the survival of republican ideology during the rise of liberalism. Finally, though Steven Watts also looks at the role of actual war in forging a peculiarly American brand of liberalism, he explores war as discourse, for instance, in the way that early political elites believed that war regenerated the polity. Among historians in this area, Marc Kruman is perhaps the only synthetic figure in that he uses "martial rhetoric" to demonstrate that the second party system was rooted in the ideology of revolutionary republicanism. Nevertheless, like other historians of party, Kruman's overall focus is the way in which revolutionary republicanism shaped the emerging theory of party. ${ }^{19}$

18. Wallace, "Changing Concepts of Party in the United States," 479

19. Richard Jensen, The winning of the Midwest: social and political conflict, 1888-1896 (Chicago and London: University of Chicago Press, 1971), 11-12, 164-174; Jean H. Baker, Affairs of Party: the Political Culture of Northern Democrats in the Mid-Nineteenth Century (Ithaca: Cornell University Press, 1983), 287-291; Jean H. Baker, "From Belief into Culture: Republicanism in the Antebellum North," American Quarterly 37 (1985): 545-549; Steven Watts, The Republic Reborn: War and the Making of Liberal America, 1790-1820 (Baltimore and London: The Johns Hopkins University Press,
The most important gap in Kruman's treatment of martial discourse, however, is the absence of the dynamic tension between antipartyism and partyism that Leonard captures in his account of Van Buren constitutionalism. This paper fuses Kruman's use of martial rhetoric as revolutionary imagery with Leonard's unique interpretation of the party-antiparty paradox. The resulting synthesis highlights the interdependence of partisanship and antipartyism within martial rhetoric and the importance of that interdependence for overcoming antipartyism and stabilizing the political system. This account of martial discourse, then, is not intended to supplant the reigning interpretations of this period, thereby advancing an alternative monocausal (and ultimately unsatisfying) account of the transition in question, but is offered instead as a neglected chapter to be integrated into the existing historiography.

\section{DATA, CASE SELECTION, AND METHOD}

To show how my claims about martial discourse scale up and down the different levels of party organization, I have collected data on three sets of political actors. $^{20}$ First, I make use of the private papers of the period's most prominent national statesmen, the complete collections of which are published in bound volumes. The paper draws on the correspondence of George Washington, Alexander Hamilton, John Adams, Thomas Jefferson, James Madison, and James Monroe for the first party system and draws on that of John Quincy Adams, Andrew Jackson, Martin Van Buren, and Henry Clay for the transition to the second party system. Secondly, to document the character of martial discourse among local elites, I have collected qualitative archival data with special attention to historical newspapers. Early nineteenth century newspapers were the official organs of the political parties. Saul Cornell's work on Antifederalist dissent suggests that newspapers were the principal means through which the far-flung political elites of the early Republic tied their parties together in a common public sphere. Finally, with respect to voters, Robertson notes, "The principal vehicle for conveying the rhetoric and practice of mass partisanship was a growing network of newspapers" through which "the web of relationships between editors, correspondents, and readers grew and thickened." For

1987), 88-92; Kruman, "The Second American Party System," $523-525$.

20. I have done my best here to show how my claims about martial discourse in Chicago and Tuscaloosa scale up to claims about national party discipline. For instance, I have tried to bring out the continuities in the use of the discourse by national elites, local elites, and local voters, but the state and regional levels of analysis are inevitably absent. My compromise position has been to complement a broad national-level overview with a more finegrained analysis of discursive dynamics on the ground. 
that reason, I draw on the same newspapers for evidence of positive audience reception of martial discourse. I focus in particular on the meetings of local rank-and-file voters, the minutes of which were often published in their respective party organs. ${ }^{21}$

This paper is part of a larger research project on the advent of liberal democracy in the United States. It continues similar work by the author on Chicago party politics and democratization by offering a southern comparison case and by outlining the pre-history of Barrington Moore's "last capitalist revolution." Given the broad framework of which this paper is a part, the immediate question arises, "why examine local cases at all?" The answer in brief is that national parties did not have a separate institutional identity from their state and local affiliates as they do now. National parties were confederations of state and local party machines. ${ }^{22}$ To be sure, Washington and Jackson were not merely the heads of state and local parties (indeed, that is why we draw on their private papers here), but as a general rule, to speak of nationally prominent elites in the nineteenth century was to speak of the most powerful state and local party chieftains.

But why Illinois and Alabama? First, any number of states would have made promising cases, but Illinois and Alabama are better suited than some. In South Carolina, for instance, electoral competition revolved around two factions of the same party, rather than a two-party system as such. Moreover, Illinois and Alabama joined the Republic at roughly the same historical conjuncture (1818-1819), the eve of the Missouri crisis and the Panic of 1819. Additionally, as Formisano rightly notes in his study of the ethnocultural basis of mass party formation in Michigan, the politics of frontier states offer more insight into the character of mass party discipline as it spread and became a more generalized political practice than older states like New York and Virginia where proparty elites were already concentrated. ${ }^{23}$ Lastly,

21. Saul Cornell, The Other Founders: Anti-Federalism and the Dissenting Tradition in America, 1788-1828 (Chapel Hill: University of North Carolina Press, 1999); Andrew W. Robertson, "Voting Rites and Voting Acts: Electioneering Ritual, 1790-1820," in Beyond the Founders: New Approaches to the Political History of the Early American Republic, eds. Jeffrey L. Pasley, Andrew W. Robertson, and David Waldstreicher (Chapel Hill: University of North Carolina Press: 2004), 67-68. For a source on newspapers as party organs, see Paul Starr, The Creation of the Media: Political Origins of Modern Communications (New York: Basic Books: 2004).

22. Roy Franklin Nichols, The Disruption of American Democracy (New York: Macmillan, 1948), 8; William E. Gienapp, The Origins of the Republican Party, 1852-1856 (New York and Oxford: Oxford University Press, 1987), 6; Leonard, Invention of Party Politics, 9.

23. Ronald P. Formisano, The Birth of Mass Political Parties, Michigan, 1827-1861 (Princeton: Princeton University Press, 1971), 4, 15, 22-23. See also Richard P. McCormick, The Second American Party System: Party Formation in the Jacksonian Era (Chapel Hill: University of North Carolina Press, 1966) and Leonard, Invention of Party Politics, 10.
Illinois and Alabama were the political epicenters of their sections leading up to the Civil War: Abraham Lincoln and Stephen A. Douglas, the presidential nominees of the national Republican and Democratic Parties respectively, were both from Illinois, and Alabama was home to the first capital of the Confederacy and arguably its most outspoken proponent, William L. Yancey.

The local cases of Chicago and Tuscaloosa, in turn, were chosen for two reasons. First, in the early Republic the two towns were similarly positioned within their states. Chicago was emerging as the center of political power in northern Illinois and became an important trading center when a harbor and canal were built to connect downstate Illinois to New York and Europe by way of the Erie Canal in the East. Similarly, Tuscaloosa was Alabama's capital until the mid-1840s, and with its position at the head of the Black Warrior River, it linked the yeoman economy of northern Alabama to the plantation economy and Gulf Coast commercial hub of Mobile to the South. At the same time, Chicago and Tuscaloosa's differences provide an opportunity to observe how mass party discipline operated in somewhat divergent contexts, with the former being a mainly urban Democratic stronghold and the latter being a more rural Whig stronghold.

I employ two methodological techniques from comparative and historical research to make claims about the role of martial discourse in mass party competition. First, I use counterfactual reasoning to show not only that the presence of mass party discipline blunted the challenges to elite legitimacy posed by the competition for voters (the proverbial "just so" story), but also that in the absence of mass party discipline, challenges to elite legitimacy deepened to the point of national crisis. ${ }^{24}$ In the first half of the empirical section I describe what American politics looked like without a such a mechanism, paying special attention to two crises: the first culminating in the presidential election of 1800 and the second culminating in the economic panic and Missouri crisis of 1819 .

I borrow the second technique from two separate literatures. Research on European class formation has shown that eighteenth- and nineteenth-century

24. For the use of counterfactual reasoning in the social sciences, see Max Weber, From Max Weber: essays in sociology, ed. H. H. Gerth and C. Wright Mills (New York: Oxford University Press, 1946), 166, 171, 180; Maurice Zeitlin, The civil wars in Chile, or, The bourgeois revolutions that never were (Princeton, NJ: Princeton University Press, 1984), 18; Howard Kimeldorf, Reds or Rackets? The Making of Radical and Conservative Unions on the Waterfront (Berkeley and Los Angeles: University of California Press, 1988), 3; Larry Griffin, "Narrative, Event-Structure Analysis, and Causal Interpretation in Historical Sociology," American Journal of Sociology 98 (1993): 1101; Manali Desai, "The Relative Autonomy of Party Practices: A Counterfactual Analysis of Left Party Ascendancy in Kerala, India, 1934-1940," American Journal of Sociology 108 (2002): 626. 
workers judged the legitimacy of incipient capitalist practices, not in terms of newer ideas like socialism, but in terms of older, established discourses. Sewell, for instance, held that the ideologies of French workers through the revolutions of 1789, 1830, and 1848 originated, and subsequently evolved out of, "the prerevolutionary corporate system." ${ }^{25}$ Historiographers of colonial North America have made similar arguments about the staying power of preexisting cultural idioms, for example, in precipitating the American Revolution. ${ }^{26}$

To give analytical weight to cultural mechanisms, the above analysts often trace the historical pathways through which inherited idioms become distorted and then give rise to new practices. Richard White uses this technique in theorizing the process of accommodation between Europeans and Indians prior to 1815. Each set of actors, White argues, brought to their prolonged encounter preconceived notions of the other, which clashed to produce fruitful misunderstandings:

\begin{abstract}
Diverse peoples adjust their differences through what amounts to a process of creative and often expedient, misunderstandings. People try to persuade others who are different from themselves by appealing to what they perceive to be the values and practices of those others. They often misinterpret and distort both the values and the practices of those they often deal with, but from these misunderstandings arise new meanings and through them new practices. ${ }^{27}$
\end{abstract}

Taking my cue from White and others, I devote a subsection below to the distortion of inherited discursive practices, namely first-party system electioneering rituals, the defensive prerogative of revolutionary republicanism, and the concept of war as regenerative of the polity. From there I am able to show that martial discourse-an amalgamation of these distorted practices-worked to stabilize the political system by providing an idiom through which a) previously antiparty elites could embrace their turn to party organization, b) local elites could find an

25. William H. Sewell, Jr., Work and revolution in France: The language of labor from the old regime to 1848 (Cambridge and New York: Cambridge University Press, 1980), 2. See also Craig Calhoun, "The Radicalism of Tradition: Community Strength or Venerable Disguise and Borrowed Language?" American Journal of Sociology, 88 (1983): 886-914; Margaret Somers, "Narrativity, Narrative Identity, and Social Action: Rethinking English Working Class Formation," Social Science History 16 (1992): 591-629; E. P. Thompson, "The Moral Economy of the Crowd," in Customs in Common: Studies in Tradition and Popular Culture (New York: New Press, 1991), 185-258.

26. See, for example, Bernard Bailyn, The Ideological Origins of the American Revolution (Cambridge, MA: Belknap Press of Harvard University Press, 1967); Richard White, The middle ground: Indians, empires, and republics in the Great Lakes Region, 1650-1815 (Cambridge: Cambridge University Press, 1991).

27. White, The middle ground, $\mathrm{x}$. identity within the larger mass party apparatus, and c) voters on the ground could actively participate in elective politics.

This is not a "causal" argument in the conventional sense of the term. To my knowledge, there are no transcripts of meetings in which prominent antebellum politicians explicitly proposed martial discourse as a strategy for overcoming antipartyism. However, the evidence does suggest that martial discourse appeared in its partisan form in the second party system, but not in the first; that its use was pervasive in the second party system; that its partyist and antiparty dimensions meshed with the emerging theory of party; and that its effect was to legitimize mass party competition and thus recruit others to the practice thereof.

The fourth kind of evidence bears further clarification here, as it comprises the bulk of the data in the second half of the empirical section below. The available data gesture toward what Althusser has referred to in another context as "interpellation," defined as the process through which people come to recognize themselves as subjects in ideological practice. ${ }^{28}$ Thus, while the primary sources do not offer any "smoking gun" or moments of conversion, they do reveal an unfolding process in which national elites, local operatives, and the rank-and-file came to recognize themselves as Democrats and Whigs. I argue that martial rhetoric, because of the distinct way in which it articulated the party-antiparty mix, was one element in the overarching party discourse that enabled the process of mass party identification.

One last prefatory remark. Although military references to the American Revolution are plentiful in my sample of primary materials, not all such rhetoric, in my view, need mention Bunker Hill or George Washington explicitly to qualify as a martial reference to the revolution. Moreover, some martial references recall the Revolutionary War and the War of 1812 at the same time. The latter was particularly germane to the second party system because of its partial inducement of electoral reform and its establishment of General Andrew Jackson as a national symbol. Finally, such references were not purely militaristic in character, but rather were used in combination with other tropes to undermine the legitimacy of political adversaries. For instance, class inequality figured prominently in the Democratic deployment of martial discourse, such that the tyrants standing in for King George were bankers, speculators, and their putative allies in the Whig Party. What is more important than providing either explicit or purely military references to the revolution is demonstrating why martial discourse helped to overcome the

28. Louis Althusser, "Ideology and Ideological States Apparatuses: Notes Towards an Investigation," in Lenin and Philosophy and Other Essays (London: Monthly Review Press, 2001 [1969]), 174. 
antipartyism of the early Republic and thus stabilize political conflict.

\section{FACTIOUS REVOLUTIONARIES: ANTIPARTYISM AND THE CRISIS OF ELITE LEGITIMACY}

In the absence of mass party discipline, political elites failed repeatedly to resolve the contradiction posed by the constitutional phase of American democratization, namely that the Constitution furnished political elites with a new resource-voters-with which to compete, even as it opened elites to unprecedented challenges to their legitimacy from both the electorate and elite challengers. Equipped only with republican ideology and a constitution that was hostile to political parties, post-revolutionary elites plunged the nation into two successive crises of elite legitimacy: the election of 1800 in which nothing less than the threat of civil war secured the accession of Thomas Jefferson to the presidency, and a subsequent period of one-party rule beginning in 1815 that factionalized the Republic along economic and regional lines and ended in a five-way race for the White House, the abortive resolution of which left many wondering whether the election of President John Quincy Adams was in fact a fraud. Like the first, the second crisis demonstrates the absence of any reliable mechanism to resolve dissent peacefully and thereby confer legitimacy upon governing elites.

I frame my account of the crisis of 1800 by dispensing with the alternative hypothesis that the crisis was fundamentally one of partisan succession. Whereas in 1796 the presidency had passed between two leaders of the same party (Washington to Adams, both Federalists), the literature suggests that in 1800 it was passed for the first time from one party to another, that is, from Adams to the Republican, Thomas Jefferson. ${ }^{29}$ In this half of the first empirical section, I argue that the crisis at its core was neither one of succession nor one that gave birth to a mature party system in which competing elites accepted the principle of the alternation of power.

Let us first take up the question of succession. The conflict over succession merely amplified a prior unwillingness on the part of competing postrevolutionary elites to countenance dissent or permit legal opposition. Early elites had assumed

29. Susan Dunn, Jefferson's Second Revolution: the Election Crisis of 1800 and the Triumph of Republicanism (New York: Houghton Mifflin, 2004), 214-215; John Ferling, Adams vs. Jefferson: the Tumultuous Election of 1800 (New York: Oxford University Press, 2004), 201; John H. Aldrich, "The Election of 1800: The Consequences of the First Change in Party Control," in Establishing Congress: the removal to Washington, D.C. and the election of 1800, eds. Kenneth R. Bowling and Donald R. Kennon (Athens, OH: Ohio University Press, 2005), 26; Edward J. Larson, A Magnificent Catastrophe: The Tumultuous Election of 1800, America's First Presidential Campaign (New York: Free Press, 2007), 270. that the institutional counterweights of the presidency, Senate, and House would by themselves resolve political conflict without recourse to parties, but the source of conflict lay elsewhere. ${ }^{30}$ Reflecting on Washington's troubled administration, President James Monroe hit closer to the mark:

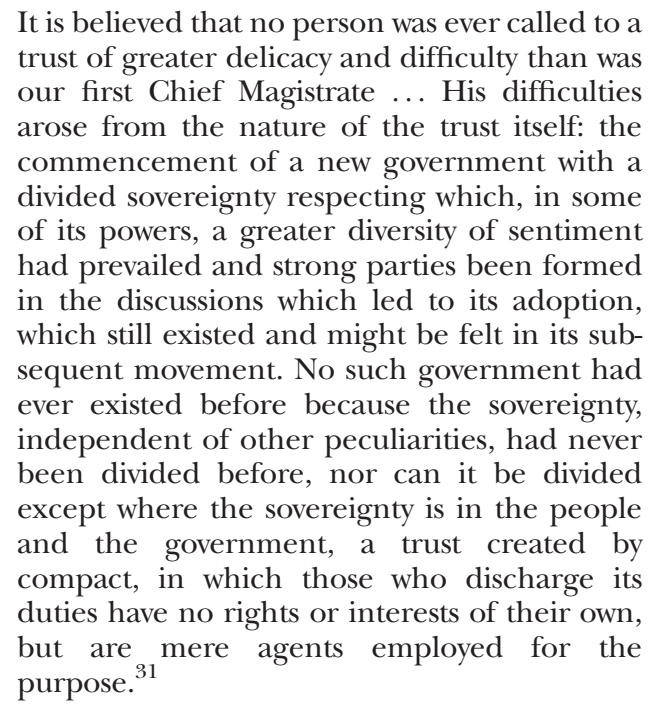

Sovereignty, in other words, had resided in the single person of the monarch but was now divided between the people and the government, giving rise to "a greater diversity of sentiment" and "strong parties" over the appropriate division of power between the two. The ensuing struggle exposed a tension between the new and the old, for as Goodman writes, on the one hand, "the deferential style of politics lingering from the past assumed that a disinterested, virtuous, and wise few were entrusted with power," but on the other hand, "party politics assumed that no group had either a prescriptive right to govern or an inherent monopoly of wisdom or incompetence." 32

Though Washington's initial instinct was to make peace among the holders of these diverse sentiments (most famously between Jefferson and Hamilton), he eventually adopted a harder line against the opposition. In his "Farewell Address," Washington characterized obedience to the government as the duty of a free people:

The very idea of the power and the right of the people to establish government presupposes

30. Bernard A. Weisberger, America Afive: Jefferson, Adams, and the Revolutionary Election of 1800 (New York: William Morrow, 2000), 29.

31. James Monroe, The Autobiography of James Monroe, ed. Stuart Gerry Brown (Syracuse: Syracuse University Press, 1959), 52.

32. Paul Goodman, "The First American Party System," in The American Party Systems: Stages of Political Development, eds. William Nisbet Chambers and Walter Dean Burnham (New York: Oxford University Press, 1967), 61. 
the duty of every individual to obey the established government. All obstructions to the execution of the laws, all combinations and associations, under whatever plausible characters, with the real design to direct, control, counteract, or awe the regular deliberation and action of the constituted authorities, are destructive of this fundamental principle and of fatal tendency. ${ }^{33}$

Washington's wholesale rejection of "combinations and associations" seeking to "counteract" the policies of the Federalist legislative agenda gave rise to state repression under his own administration and eventually set the stage for the Alien and Sedition Laws of 1798 under John Adams. Indeed, the Federalists came to rely increasingly on state repression to manage elite and mass dissent. When farmers in western Pennsylvania and neighboring Virginia and Kentucky rebelled against an excise tax on distilled liquor, Washington raised an army roughly the size of the entire revolutionary militia to crush them, albeit without much incident. ${ }^{34}$

Paradoxically, Washington then blamed the rebellion on "democratic societies," which were only loosely affiliated with Republicans but were framed by the Federalists as the heart and soul of the party. Alarmed at the prospect of further state repression, even Republicans denounced the societies for handing the Federalists an excuse to smear them as traitors. Jefferson was more sympathetic with the fringe element of his base and denied the existence of a bona fide insurrection, but he admitted privately to Madison that the "occasional riots" had allowed the "employing of military force for civil purposes" and "answered the favorite purposes of strengthening government." 35 Thus, although the Federalists suspected the Republicans of inciting rebellion, the situation was in fact far worse than they thought, for Republicans elites had little control over the democratic societies, Whiskey rebels, or Daniel Shays who were challenging the Federalist regime.

Nevertheless, as the Republic braced for war with France, the Federalists maneuvered to break the opposition permanently by raising a standing army and passing the Alien and Sedition Laws. Three alien laws subjected immigrants (a majority of whom were thought to be Jefferson sympathizers) to

33. George Washington, "Farewell address," in A Compilation of the Messages and Papers of the Presidents, 1789-1902 (Vol. I), eds. James D. Richardson and the Joint Committee on Printing, United States Senate (Washington, DC: Bureau of National Literature and Art, 1904), 217-218.

34. Sean Wilentz, The Rise of American Democracy: Jefferson to Lincoln (New York: Norton, 2005), 62-64.

35. Wilentz, The Rise of American Democracy, 64; Thomas Jefferson, "To James Madison. Monticello May 26. 1795," in The Papers of Thomas Jefferson, Volume 28, 1 January 1794 to 20 February 1796, ed. John Catanzariti (Princeton and Oxford: Princeton University Press, 2000), 359. longer naturalization periods, deportation, and imprisonment, and the Sedition Law further circumscribed the use of libelous words against the government. Madison and Jefferson responded with the Virginia and Kentucky Resolutions, which skirted the line of secession by declaring the Alien and Sedition Laws null and void. Very soon thereafter, the federal government sent troops to disperse yet another rebellion of Pennsylvania farmers who rose up this time against the newly instituted war tax. President John Adams described this period as a "critical state of things":

\begin{abstract}
When Virginia and Kentucky, too nearly in unison with the other southern and western States, were menacing a separation; when insurrection was flaming in Pennsylvania; when Baltimore, at the head of one half of Maryland, was glowing with opposition ... when the administration was threatened even in the town of Boston. ${ }^{36}$
\end{abstract}

The mounting tension in the lead-up to the crisis of 1800-1801 therefore begs the question: did Jefferson's election represent a break with this trajectory? That is, did it in fact carve out a peaceful, institutional path to mass party competition? Because there was no such path for managing dissent, none, I argue, existed for routine partisan conflict. Indeed, the strategy of the Jeffersonian opposition was to leave the national theater, build their political and military strength at the state level, and threaten secession and civil war if Federalists refused to change their policies. ${ }^{37}$ That strategy finally bore fruit in Jefferson's second run for the presidency.

The outcome of the 1800 Electoral College vote was as follows: Jefferson (73), Burr (73), Adams (65), Pinckney (64), and Jay (1). In the absence of an Electoral College majority, the Constitution mandates that the House of Representatives decide which of the top two candidates should become president, in this case, Jefferson and his running mate, Aaron Burr. The crisis developed when one portion of the lame duck Federalist majority (the Jeffersonians would control the incoming Congress) threw their votes to Burr to deny Jefferson the presidency, producing a deadlock on the first thirty-five ballots. ${ }^{38}$

36. Morton Grodzins, "Political Parties and the Crisis of Succession in the United States: The Case of 1800," in Political Parties and Political Development, eds. Joseph LaPalombara and Myron Weiner (Princeton: Princeton University Press, 1966), 310-311; James Roger Sharp, American Politics in the Early Republic: The New Nation in Crisis (New Haven and London: Yale University Press, 1993), 12-13; Ferling, Adams vs. Jefferson, 108-111; John Adams, "To James Lloyd. Quincy, January, 1815," in The Works of John Adams, Second President of the United States (Vol. X), ed. Charles Francis Adams (Freeport, NY: Books for Libraries Press, 1969), 112.

37. Sharp, American Politics in the Early Republic, 12.

38. Dunn, Jefferson's Second Revolution, 196-213; Ferling, Adams vs. Jefferson, 164-165, 172-173, 176, 192-193. 
It was the threat of civil war that ultimately compelled the Federalists to acquiesce on the thirty-sixth ballot and elect Jefferson president. Governors McKean and Monroe mobilized the Pennsylvania and Virginia militias respectively to prevent "Federal usurpation," and there were reports that the Maryland militia had planned to join them. Republicans talked openly of a convention to reorganize the government. The Federalists for their part proposed to send troops to put down the Virginia militia; some blustered that the central government could count on the 70,000 men of the Massachusetts militia. ${ }^{39}$

Private post-mortems of the crisis underscore the decisiveness of the military threat in bringing about a resolution. Jefferson wrote, "The certainty that legislative usurpation would be resisted by arms ... brought over to us the whole body of Federalists, who being alarmed with the danger of a dissolution of the government, had been made most anxiously to wish the very administration they had opposed." Madison likewise described the vulnerability of the Federalists not in political, but in military, terms: "It was thought not probable that the phalanx would hold out agst. the general revolt of its partizans out of doors \& without any military force to abet usurpation." On the other side of the aisle, James A. Bayard, head of the Federalist delegation from Delaware and the crucial swing vote during the crisis, wrote this of its resolution: "The step was not taken until it was admitted on all hands that we must risk the Constitution and a civil war or take Mr. Jefferson." To suggest, then, that parties had come of age and inaugurated a period of routinized mass party competition is to ignore the very real threat of civil war, which was greater in 1801 than in any other period except 1860 to 1861 . $^{40}$

In addition, as I have hinted earlier, competing post-revolutionary elites did not consider themselves members of parties, but of temporary coalitions forged for the purpose of destroying their adversaries and wiping out parties forever. Sharp notes, "The republicans believed that they and they alone were the interpreters and translators of the wishes of a fictive sovereign people. But so did the Federalists. Under such circumstances, there could be little tolerance of opposition, for each proto-party was dedicated to the ultimate destruction of its political

39. Grodzins, "Political Parties," 319; Sharp, American Politics in the Early Republic, 274-275; Dunn, Jefferson's Second Revolution, 206-207, 209-210.

40. Thomas Jefferson, "From Thomas Jefferson. Washington Feb. 18. 1801," in The Papers of James Madison (Volume 17, 31 March 1797-3 March 1801), ed. David B. Mattern (Charlottesville and London: University Press of Virginia, 1991), 467; James Madison, "To Thomas Jefferson. Feby. 28. 1801," in The Papers of James Madison (Volume 17, 31 March 1797-3 March 1801), ed. David B. Mattern (Charlottesville and London: University Press of Virginia, 1991), 475; Dunn, Jefferson's Second Revolution, 213; Sharp, American Politics in the Early Republic, 275. enemies, who were enemies of the people." Hamilton, for instance, asserted "the duty of a wise people to discountenance and repress" what he called "the common and continual mischiefs of the Spirit of Party." In the flush of Republican ascendancy, Jefferson likewise expressed satisfaction that the Federalists' "treasonable combinations" had at last "consigned them to the tomb of the dead." There were thus no pretensions of institutionalizing a legal opposition because Federalists and Republicans alike viewed themselves not as parties but as "embodiments of the nation's will." As Henry Adams once observed, "To crush democracy by force ... was the ultimate resource of Hamilton. To crush that force was the determined intention of Jefferson." This unyielding antipathy to parties eventually gave rise to a one-party system and a second crisis of elite legitimacy. ${ }^{41}$

That mass parties had not taken hold explains why the first party system disintegrated in the aftermath of the 1801 crisis. If the political elites of the early Republic did not see themselves as members of parties, neither did they see themselves as professional politicians. Public service was not a career, but a duty and oftentimes a burden. Those like Aaron Burr who saw it the other way were suspected, as parties were, of pursuing a private agenda that was dangerously at odds with the public good. Even Hamilton, whose adversaries condemned him as the worst partisan of them all, wrote privately to his Federalist associates in favor of Jefferson's election over Burr in 1800. To Treasury Secretary Oliver Wolcott, Jr., Hamilton expressed his preference in this way: "There is no doubt but that upon every virtuous and prudent calculation Jefferson is to be preferred. He is by far not so dangerous a man and he has pretensions to character. As to Burr there is nothing in his favour ... If he can, he will certainly disturb our institutions to secure to himself permanent power and with it wealth [his emphasis]." Because the elites of the first party system were not professional politicians, many either retired abruptly from public life (satisfied, for instance, that they had defeated the Federalists once and for all), or in the case of the post-1801 Federalists, defected to the Republicans. The eventual result was the fulfillment of the founders' republican ideal: a one-party system. ${ }^{42}$

41. Sharp, American Politics in the Early Republic, 10; Alexander Hamilton, "To Washington, Aug. 10, 1796," in The Papers of Alexander Hamilton, ed. Harold C. Syrett (New York and London: Columbia University Press, 1974), 298; Thomas Jefferson, "The Anas. 1791-1806. Selections. February 4, 1818," in Writings (New York: The Library of America, 1984), 672-673; Goodman, "The First American Party System," 57; Hofstadter, The Idea of a Party System, 8; Grodzins, "Political Parties," 318.

42. Goodman, "The First American Party System," 86-87; Ferling, Adams vs. Jefferson, 85, 211-215; Alexander Hamilton, "To Oliver Wolcott, Junior, New York Decr. 16. 1800," in The Papers of Alexander Hamilton, ed. Harold C. Syrett (New York and London: Columbia University Press, 1974), 257; Dunn, Jefferson's Second 
However, the one-party system, grounded as it was in a suspicion of party discipline, merely permitted an explosion of factions, which further undermined elite legitimacy because no one faction recognized another's prerogative to rule. The tail end of the Madison administration (1808-1816) had prefigured the fall of the Republican consensus. Antiwar New England Federalists, now nominally Republican, gathered in Hartford to threaten disunion as the War of 1812 came to a close. Once a favorable peace was made, the Federalists were disgraced as traitors but were nonetheless permitted to remain in the Republican Party. Additionally, in chartering the Second Bank of the United States in 1816, Madison simultaneously co-opted pro-bank Federalists under the banner of "National" Republicanism and alienated the adherents of "Old" Republicanism who clung to Jefferson's longstanding opposition to a strong central government. ${ }^{43}$

If the Madison administration planted the seeds of internecine rivalry, however, then it was the Monroe administration that encouraged it to grow and entangle postwar politics. Amidst the brief consensus and prosperity of the immediate postwar era, the new president expressed gratification at "the increased harmony of opinion which pervades our Union." He added, "Discord does not belong to our system," and "the American people ... constitute one great family with a common interest." Accordingly, Monroe eschewed appeals to party discipline as a means of advancing his legislative agenda, preferring instead to hammer out a consensus among his cabinet secretaries before presenting his initiatives to Congress. This method was intermittently effective because each secretary commanded his own personal following in Congress, and consensus in the cabinet typically precluded dissent in the legislative branch. However, Monroe's so-called "consolidation" policy was more often ineffective for the same reason. In his orthodox rejection of political considerations, Monroe had knowingly chosen cabinet members who were presidential aspirants, chief among these being William H. Crawford (treasury), John Quincy Adams (state), and John C. Calhoun (war). Each, in turn, used their position to cultivate surrogates in Congress, undermine the stature of the others, and contradict the president in order to appear independent and therefore presidential. Adams described the factional rancor in this way, with special attention to Crawford, who was rapidly emerging as his arch-nemesis:

Revolution, 86-87; Daniel Walker Howe, What Hath God Wrought: The Transformation of America, 1815-1848 (New York: Oxford University Press, 2007), 95; Aldrich, "The Election of 1800," 28.

43. George Dangerfield, The Era of Good Feelings (New York: Harcourt Brace, 1952), xi, 86-88, 98-99; Wilentz, Rise of American Democracy, 184.
As the old line of demarkation [sic] between parties has broken down, personal has taken the place of principled opposition. The personal friends of the President in the House are neither so numerous, nor so active, nor so able as his opponents. Crawford's personal friends, instead of befriending the Administration, operate as powerfully as they can, without exposing or avowing their motives, against it. Every act and thought of Crawford looks to the next Presidency.

The effect of Monroe's consolidation policy, then, was partly to replace the erstwhile Federalist-Republican divide with personal factionalism. The new terrain was all the more obvious when irreconcilable differences made consensus impossible because the president in these cases often advanced a bill without consulting the cabinet, whereupon the secretaries and their respective factions felt at liberty to attack the administration. ${ }^{44}$

The problem of elite legitimacy was further complicated by the doctrine of congressional superiority, a longstanding Republican orthodoxy that confined executive power to foreign affairs and assumed the primacy of the legislative branch in all other matters. The doctrine led legislators to gratuitously oppose the administration so as not to be accused of being stooges of the executive branch-this, the worst possible insult in congressional politics. John Forsyth, chairman of the House Committee on Foreign Affairs and ardent supporter of the administration, thus sponsored a resolution to seize Florida against the president's wishes to refute Henry Clay's charge that he was a White House lackey. Indeed, Monroe could prevent the consideration of a bill merely by expressing an opinion on the matter. Accordingly, John Quincy Adams observed "a perpetual struggle in both Houses of Congress to control the Executive-to make it dependent upon and subservient to them." 45

Finally, elite legitimacy was undermined still further by the debate over states' rights. Whereas Madison, Monroe and the National Republicans believed that the federal and state governments each had ultimate authority within their own spheres of influence (the doctrine of dual sovereignty), the Old Republicans articulated a confederated theory of sovereignty in which the federal

44. James Monroe, "First Inaugural Address, March 4, 1817," in James Monroe, 1758-1831: Chronology-Documents-Bibliographical Aids, ed. Ian Elliot (Dobbs Ferry, NY: Oceana Publications, 1969), 32-33; Howe, What Hath God Wrought, 92-94; Dangerfield, Era of Good Feelings, 100, 101-102, 122, 160; Harry Ammon, James Monroe: The Quest for National Identity (New York: McGraw Hill, 1971), 380-381, 384-385; John Quincy Adams, "Jan. 8, 1820," in The Diary of John Quincy Adams, 1794-1845, ed. Allan Nevins (New York: Charles Scribner's Sons, 1951), 223. 223 
government was merely the creature of the several states. Thus, when the nationalist Marshall Court denied the right of the states to tax a local branch of the Bank of the United States in McCullough $v$. Maryland, the Old Republicans revolted. Recalling the crisis of 1801, Virginia Judge Spencer Roane threatened armed defiance, and the Baltimore editor, Hezekiah Niles, urged all people who hated monopoly and privilege to rise up and "purge our political temple of the money-changers." The Pennsylvania, Tennessee, Ohio, Indiana, and Illinois legislatures acted in kind and demanded a constitutional amendment forbidding Congress to incorporate a bank. $^{46}$

The factious effects of these practices-the consolidation policy, the doctrine of congressional superiority, and the clash over states' rights-would eventually be blunted by mass party discipline because the structure and discourse of party command would stretch from the White House, through Congress, across regions and states to the rank-and-file and back again. However, in the absence of mass party discipline, these practices precipitated another crisis of elite legitimacy.

If National Republicanism remained a formidable political force through the Madison administration and Monroe's first term, it became utterly defunct with the Panic of 1819, the first peacetime depression in U.S. history. Though the causes of the panic were primarily geopolitical in nature as former stockpiles of manufactures and raw materials overwhelmed American producers after the War of 1812 and the Napoleonic Wars, the enemies of the administration could justifiably point their fingers at the mismanagement of the Bank of the United States (BUS). Through pure negligence the BUS had allowed its local branches to extend credit to land speculators and farmers beyond the amount of gold specie they had to back those loans, creating a bubble in property values that burst when the price of cotton fell to reflect the postwar glut. The resulting depression unleashed a torrent of divisions to add to the already factious soup of presidential aspirants and Old and National Republicans: hard versus soft money, pro- and anti-bank, advocates and opponents of economic retrenchment, tariff and anti-tariff. The absence of party command deepened the financial debacle. The president had attempted to mitigate the crushing influx of cheap imports by presenting a tariff bill to Congress, but because the cabinet was divided on the issue, Monroe did not consult them, releasing his secretaries and other adversaries to finally scuttle the bill in the Senate. Henry Clay, then Speaker of the House, mocked Monroe's consolidation policy as he clamored for economic retrenchment:

46. Dangerfield, Era of Good Feelings, 172-174.
Instead of assembling them together and saying in an authorative $[s i c]$ tone, Gentlemen here are our means; reduce your expences [sic $]$ within them; and if they will not settle the matter among themselves, fixing himself how much each shall be reduced, he permits every one of them in Congress to exert the whole force of his own little coterie, backed by the name of the administration, and thus to defeat every project of oeconomy $[s i c] .{ }^{47}$

The absence of mass party discipline likewise permitted sectional conflicts to emerge as the Congress considered the admission of Missouri to the Union. Three parties were active in the dispute, the Federalist, National Republican, and Old Republican, and these in turn split into geographical factions that either opposed or advocated the right of the central government to "restrict" slavery in the territories. Thus, otherwise nationalist elites like John C. Calhoun and William Lowndes of South Carolina became anti-restrictionists, and longstanding inter-regional alliances like that of Pennsylvania and Virginia fractured. ${ }^{48}$

Though the Missouri Compromise was eventually reached, it was not party discipline that made it possible but rather the same kinds of threats that resolved the crisis of 1801 . In private correspondence, Henry Clay wrote, "The words, civil war, and disunion, are uttered almost without emotion, and a Senator of the United States, in this place, as I understand, said the other day that he would rather have both than fail in the resolution." Echoing the sentiments in the Senate, Judge Spencer Roane warned the president that he would rather take the South out of the Union than be "damned up in a land of slaves by the Eastern people." The rationale that congressmen gave for switching their votes to compromise suggests that the prospect of civil war and disunion was once again the decisive factor leading to the end of a national crisis. Representative Charles Kinsey of New Jersey said to his colleagues, "Should we persist to reject the olive branch now offered, the most disastrous consequences will follow." Jonathan Mason of Massachusetts "was also distraught at 'one half of the Union in complete array against the other, by a geographical line." Mark Hill, Mason's colleague in the Massachusetts delegation, said he "would do whatever he could to restrict slavery, but "without setting

47. Dangerfield, Era of Good Feelings, 176-179, 188; Ammon, James Monroe, 462-464, 471; Andrew C. Lenner, The Federal Principles in American Politics, 1790-1833 (Lanham, MD: Rowman and Littlefield, 2001), 114, 123-124; Wilentz, Rise of American Democracy, 205207, 209, 217; Henry Clay, "To Jonathan Russell, Washington 10 h. April 1820," in The Papers of Henry Clay, Volume 2, The Rising Statesman, 1815-1820, ed. James F. Hopkins (Lexington, KY: University of Kentucky Press, 1982), 819.

48. Dangerfield, Era of Good Feelings, 237, 242; Ammon, James Monroe, 445, 449-450; Lenner, Federal Principles, 124, 126-127, 130-134, 137-138; Wilentz, Rise of American Democracy, 219, $231-232$. 
the United States on fire." Congressman Bernard Smith explained, "I did what I considered necessary to prevent a dissolution of the Union." 49

In his diary, John Quincy Adams summed up the so-called Era of Good Feelings in this way:

\begin{abstract}
The bank, the national currency, the stagnation of commerce, the depression of manufactures, the restless turbulence and jealousies and insubordination of the State Legislatures, the Missouri slave question, the deficiencies of the revenue to be supplied, the rankling passions and ambitious projects of individuals, mingling with everything, presented a prospect of the future which I freely acknowledge was to me appalling. ${ }^{50}$
\end{abstract}

It should be no surprise, then, that the election of 1824, in which Adams himself was a player, produced no fewer than five major candidates for the presidency, each representing personal and regional factions too weak to carry a majority of Electoral College votes. Though Calhoun eventually dropped out of the race, the remaining four-way split threw the election to the House of Representatives for the first time since $1801 .^{51}$ Such was the normal and expected state of things that most partisans, including Martin Van Buren, acquiesced to the will of Congress despite murmurings that President-Elect Adams had promised Henry Clay the position of secretary of state in exchange for his support in the House, the so-called "corrupt bargain." Andrew Jackson, the front-runner in the late election before its congressional phase when Adams prevailed, was decidedly not acquiescent however, and it was around this sentiment that Van Buren and his cohort coalesced to form a permanent Jeffersonian party.

\section{VICARIOUS REVOLUTIONARIES: MARTIAL DISCOURSE AND THE STABILIZATION OF MASS PARTY POLITICS}

The first party system, then, was not a mass party system. Instead of mass mobilization, early national elites depended on violence, threats of civil war and disunion, and the federal courts to decide the political questions of the day. All these factors made elites vulnerable to successive crises of legitimacy. At that moment, however, the political operatives of the second party system recuperated and reconstituted

49. Henry Clay, "To Adam Beatty, Washington, January 22, 1820," in The Papers of Henry Clay, Volume 2, The Rising Statesman, 1815-1820, ed. James F. Hopkins (Lexington, KY: University of Kentucky Press, 1982), 766; Ammon, James Monroe, 455; Lenner, Federal Principles, 137-138.

50. Adams, "Jan. 8, 1820," 224.

51. Martin Van Buren, Inquiry into the Origin and Course of Political Parties in the United States (New York: A. M. Kelley, 1867), 3; Ammon, James Monroe, 459; Harry Watson, Liberty and Power: the Politics of Jacksonian America (New York: Noonday Press, 1990), 81; Wilentz, Rise of American Democracy, 252. the quasi-military discursive practices of their predecessors to craft an idiom for mass politics that turned on the binary struggle between the putative descendants of the British aristocracy on the one hand and the undivided ranks of second generation patriots on the other. Thus, together with the theoretical strands of party discourse, martial rhetoric helped to stabilize the party system by providing an acceptable framework through which a) antiparty national elites could embrace their turn to party organization, b) local elites could find their identity in the emerging mass party apparatus, and c) voters could participate actively in elective politics. Martial discourse, in other words, aided in recruiting these different sets of political actors to the practice of mass partisanship and thereby contributed to the stabilization of partisan conflict.

\section{Discursive Origins of Social Change}

Martial discourse grew out of three inherited discursive practices: electioneering rituals, the defensive prerogative of revolutionary republicanism, and the concept of regenerative war. First, though many of the revolution's "minutemen" were volunteer guerrilla fighters, the electioneering rituals of the first party system were highly regimented affairs that more closely approximated the maneuvers of professional armies. Federalist street processions, for instance, were orderly parades designed to persuade entire communities to unify behind essentially conservative positions. Republicans employed the military form to organize young working class men at election time. In Philadelphia, one such organization was called the "Democratic committee of vigilance," and in Pittsburgh local ward bosses used military terms such as "enlistment," "brigade," and "brigadier general" to organize their canvassing operations. A contemporary of eighteenth century electioneering ritual thus observed, "The parties were drilled to move together in a body." Early political elites in effect re-imagined the patriots of the American Revolution into the trained soldiers of a permanent standing army and then insisted that their constituents follow "their example." This slippage worked to destabilize the old discursive order by providing a revisionist historical basis for permanent party organization. $^{52}$

Second, mass party elites seized selectively on the defensive prerogative in republican discourse, which was distilled perhaps most famously in the work of

52. Robertson, "Voting Rites and Voting Acts," 61, 69, 71, 74; Robert H. Wiebe, The Opening of American Society: From the Adoption of the Constitution to the Eve of Disunion (New York: Alfred A. Knopf, 1984), 103; Jean Baker, "From Belief into Culture," 547; Edward Patchell, "Edward Patchell to Andrew Jackson. Pittsburg [sic], August 7, 1824," in Correspondence of Andrew Jackson, Volume III, 1820-1828, ed. John Spencer Bassett (New York: Kraus Reprint Co, 1969), 262-264. 
the English Country Whig, Henry St. John, Lord Bolingbroke. In A Dissertation upon Parties and The Idea of a Patriot King, Bolingbroke offered his rationale for organizing an opposition party against Sir Robert Walpole, who, in his view, sought to subject the Parliament, representative of the rights of the country, to the kingly court. Bolingbroke believed that combination was treasonous as a general rule but was the highest form of patriotism whenever wicked men conspired to undermine the constitution. Accordingly, such action was always meant to be self-liquidating: when the conspiracy was defeated, the opposition would dissolve, and a patriot king would gather unto himself a group of virtuous men to govern in the interest of the entire country instead of the selfish few. ${ }^{53}$

Eventually, however, incipient Democrats would drop the self-liquidating imperative of Bolingbroke republicanism, citing a permanent security risk to the new Republic. Routing out a fifth-column "aristocracy" required a permanent disciplinary device that could unmask otherwise unidentifiable traitors. Van Buren reasoned that the only viable weapon against this crypto-nobility was permanent party organization, which, he argued, using the wartime language of espionage and infiltration, would serve to "excite a salutary vigilance over our public functionaries" and "tear the masks from several, who without having been exposed ... might have been able ... to have passed for what they are not." 54

A third source of martial discourse was the republican concept of regenerative war. As Kruman writes, "The martial rhetoric of the parties also expressed the continuing republican belief ... that war affirmed, celebrated, and regenerated the polity." Henry Clay, for example, advocated war with Great Britain in 1812 because prolonged peace and prosperity had, in his view, weakened the American polity. Thus, Clay intoned, "I prefer the troubled ocean of war, demanded by the honor and independence of the country with all its calamities, and desolations, to the tranquil, putrescent pool of ignominious peace. ${ }^{55}$ The emergence of martial discourse as a justification for mass party competition therefore depended on the misapplication of the concept of

53. Hofstadter, Idea of a Party System, 10, 18-23, 33-34; Wilson, "Republicanism and the Idea of Party," 423-424, 430.

54. Hofstadter overstates the irreconcilability of Bolingbroke's theory of party on the one hand and those of Edmund Burke and Van Buren on the other. The data suggest that Van Buren selectively exploited the defensive prerogative of Bolingbroke republicanism to justify permanent party organization. Van Buren, Inquiry, 5, 422; Martin Van Buren, "Martin Van Buren to Jackson. London, October 11, 1831," in Correspondence of Andrew Jackson, Volume IV, 1829-1832, ed. John Spencer Bassett (New York: Kraus Reprint Co, 1969), 355; Van Buren, Autobiography, 512.

55. Kruman, "Second American Party System," 524; Watts, The Republic Reborn, 92. regenerative war from military warfare where Clay had originally intended it, to political warfare where Clay and his compatriots later redirected it. Critical to the concept of regeneration was the binary of decay and corruption on the one hand, and the purifying potential of war on the other. The word "campaign," then, was indigenous to martial, not political, discourse. Eventually the "political campaign" came to be seen as a mechanism for clearing away the corruption or rot that had been preying on the vitals of the nation.

Together, the reinvention of the revolutionary militia, the defensive prerogative, and regenerative war worked to rehabilitate the political party as an army for the orderly and permanent defense of the Republic, not necessarily against an external foe, but more often against the internal threat of moral decay and corruption. Accordingly, the rhetoric of political warfare often involved two interlocking themes: patriotic solidarity and relentless pursuit of a hidden, fifth-column aristocracy. Martial rhetoric therefore shared in the theoretical foundations of partyist discourse, but it was its mass appeal and recruiting capacity that concerns us here. In the next subsection, we explore the ways in which leading antiparty politicians came to accept mass partisanship through the language of martial discourse.

\section{Social Change at the Top}

When the principal factions of the second generation elite began to compete in earnest for the leadership of the Republic after 1824, each turned to partisan organization for advantage but embraced their shift in strategy using martial metaphors. For example, after the Adams administration's demoralizing loss in New York, where victory was all but assured with the opposition split between Democrats and Antimasons, Henry Clay explained the defeat to his colleague, William B. Lawrence, in this way:

\section{The [Albany] Regency and the Antimasons were both organized; our friends were not. The consequence was that both of the former parties went to the polls with their forces mar- shalled $[s i c]$ and with objects in view, whilst our friends repaired to them, helter skelter, leaving things to take what course they might... . Let us march directly to our object. It is the manly course. Let us hoist our banner and rally our friends and organize them for systematic action.}

Rather than continue exclusively with the bureaucratic theme of "organization" where his explanation began, Clay switches metaphors, preferring instead to contrast the marshaled forces of the opposition with those of the Adams administration who repaired to them helter skelter. Clay might have also framed a remedy to his party's disorganization in any number 
of ways, but he returned instead to the metaphor of the battlefield. Faced with the prospect of future losses to an organized opposition, Clay drew on the revisionist view of the revolutionary militia as a professional army and urged his colleagues to act more like trained soldiers, to "march," to hoist their "banner," and to "rally."

As a key advisor to the Adams administration, Clay was naturally suspicious of oppositional politics, but General Andrew Jackson, the first figurehead of the Democratic Party, was no less suspicious. As late as 1824 when Martin Van Buren called a congressional caucus (precursor to the modern party convention) to nominate a presidential candidate, Jackson refused to attend. Upon winning his presidential re-election campaign in 1832, however, Jackson, once the reluctant partisan, now wrote to Van Buren explaining the need for the Democratic Party in this way:

\begin{abstract}
Wisdom says, be always guarded against the council and combination of the wicked, the precaution suggested is one of safety ... The opposition is broken and scattered, still tho scotched not dead, and it behooves us to proceed to unite and give energy to our democratic brethren [his emphasis].
\end{abstract}

In this passage, Jackson repeats Van Buren's version of the defensive prerogative. Unlike Bolingbroke, he argues for a permanent defense to "guard" against a "combination of the wicked." For although the opposition is "broken and scattered" like a defeated army, they are still "not dead." Given this weak but desperate foe, Jackson councils "safety" and urges Van Buren, even in the full flush of his re-election victory, to continue to "unite and give energy" to the Democratic Party. ${ }^{57}$

Thus, in the emerging encounter between the competing factions of the second-generation elite, previously antiparty statesmen became convinced (and subsequently tried to convince others) of the need for party discipline through the use of martial imagery. Clay exhorted his party to behave more like a professional army, and Jackson argued for a permanent partisan bulwark against the defeated opposition. In the next subsection, we examine how the logic of martial discourse enabled local elites in Chicago and Tuscaloosa to find their identity in the mass party apparatus.

56. Henry Clay, "To William B. Lawrence, Lexington, November 21, 1830," in The Papers of Henry Clay, Volume 8, Candidate, Compromiser, Whig, March 5, 1829-December 31, 1836, ed. Robert Seager II (Lexington: The University Press of Kentucky, 1984), 300-301.

57. Andrew Jackson, "To Martin Van Buren, Washington, November 18, 1832," in Correspondence of Andrew Jackson, Volume IV, 1829-1832, ed. John Spencer Bassett (New York: Kraus Reprint Co., [1928] 1969), 489.

\section{Social Change in the Middle}

Local party elites appear to have embraced one of two identities in the party system. One such identity was that of sentinel or guardian to the local party. An early Jacksonian organ in Tuscaloosa called the Flag of the Union responded to the growing hostility to the Jackson administration by saying, "We are apprehensive we cannot with the faithful watchman of the night, cry out, 'all's well'" (Flag of the Union, 11 July 1833). Likewise, Congressman William R. Smith, editor of Tuscaloosa's Whig organ, the Independent Monitor, made sense of his own role in the party in this way:

\begin{abstract}
A free press in a free country, ought to be the guardian of liberty; and all who share in directing its influence should feel themselves invested with the responsibilities of sentinels upon the watchtowers of freedom. But a press prostituted to unworthy purposes becomes faithless to this high trust, and its most dangerous of all foes, to the true principles of liberty-precisely as treachery is more formidable, than all the machinations of open hostility. (Independent Monitor, 1 December 1838)
\end{abstract}

The binary logic of the revolution is palpable in this passage. Smith argues in vivid martial prose that those like him, who direct the influence of the press, are the "guardian of liberty" and the "sentinels upon the watchtowers of freedom." Accordingly, those editors who abuse that trust are the "most dangerous of all foes" to the cause of liberty, for instead of engaging in "open hostility," they perpetrate a subtle "treachery" against the Republic itself.

When local elites did not explicitly call themselves "sentinels" or "guardians," they behaved matter-of-factly as if they were. In this excerpt from Tuscaloosa's Democratic Gazette, the editor reviews Whig strategy with the gaze of a sentinel perched on high, surveying the movements of the opposing army below:

\begin{abstract}
They desert the old and plain path of honesty and fair dealing, for one bordered by ravines and bushes, and other places of concealment; they shun the hill top, lest they should be seen in the clear atmosphere of truth, and seek the swamp and the dell, that when their disguises fail them they may conceal themselves. (Democratic Gazette, 12 December 1843)
\end{abstract}

The editor of the Gazette does three things at once in this passage. First, he exploits the well-worn martial themes of espionage and infiltration used earlier by Van Buren to describe those who pretend to be Democrats in order to win office. Second, in his desire to discipline the Democratic base, the Gazette's editor conveniently forgets that the revolutionary militia's only chance of victory against a predictably regimented British army were the very same 
unpredictable tactics that he now denounces as cowardice and concealment. Finally, the editor, unlike Van Buren, goes out of his way to construct a very particular vantage point; he surveys the terrain of the political battlefield from the perspective of a watchman, and, having detected the Whigs' maneuver, then sounds the alarm to "rally to the standard of the defeated leader of 1840," former President Martin Van Buren.

A year later, Tuscaloosa Democrats published a weekly campaign sheet, whose prospectus described the paper as the protector of the local Democratic cause. Again the rationale for printing the sheet was framed in martial terms: "It is the antidote by which, to check the inroads of political fraud and misrepresentation-the weapons by which alone, the democratic party will be assailed" (Democratic Mentor, 20 March 1844). The editor thus asserts that the Democrats will be unbeatable so long as he keeps the party's principles before the people and guards-as an "antidote" does the body-against Whig "fraud and misrepresentation," the only "weapons" by which the party can be "assailed." The editor then lays out the party's platform and ends with a rhetorical flourish in which he confers upon himself the solemn duty of preparing the Democratic army for war. "With those principles inscribed upon our standard," he proclaims, "we are ready to enter the field of combat."

A second but equally important identity embraced by local elites was that of mid-level commander whose job it was to simultaneously urge the army into battle and unify the ranks. As the financial panic of 1837 set in, for example, Congressman John Wentworth, the Chicago Democrat's editor, called on his brethren to wage war against Nicholas Biddle, head of the Second Bank of the United States. In doing so, he expressed the more aggressive oppositional tendencies of the new mass partisanship:

Let us a wage a war of extermination against Bank minions, Bank advocates and Bank owners! ... The battle field is before us-the golden troops of Biddle are in martial array, and let us vanquish them or perish in the last ditch. (Chicago Democrat, 16 July 1837)

Here Wentworth cloaks the political conflict over the panic in the binary logic of the revolution while simultaneously recalling the "Indian Removal" campaigns that had made Andrew Jackson a war hero and, in turn, a presidential contender. Bank minions, advocates, and owners comprise the aristocratic ("golden") troops of Nicholas Biddle who are in ominous "martial array," whereas the patriotic non-elite victims of the crisis, presumably all rank-and-file Democrats, comprise the "us," whom Wentworth exhorts-like General Jackson before him-to wage a war of nothing less than "extermination."
In the heat of the 1840 presidential race, William Stuart, the editor of the Whig Chicago American, likewise embodied the role of the aggressive mid-level commander:

WHIG EDITORS! We call on you in the language of the Globe, to "abandon your defensive-warfare, and charge home upon the enemy." The old Hero needs no apologies at your hands!-Your duty now is to expose the corrupt practices of this rotten administration. Do not spare the knife! — do not spare the lash! Let them have it-let them have it!- "Charge along the whole line." [their emphasis] (Chicago American, 21 August 1840)

Stuart's spirited appeal significantly outlines a chain of command, from the "old Hero" (Whig presidential candidate, General William Henry Harrison), to the Globe (the Whigs' national party organ), and then to all local party papers like his own, whose job now is to shift from a "defensive" posture and "charge home" upon the Democrats. In this way, martial language enables Stuart not only to find his place in the mass party apparatus, but also to receive "orders" for the next tactical maneuver. Note that this passage reveals a heretofore unheard of level of oppositional sentiment, one that might have been shocking to an otherwise antiparty public, but which Stuart couches in stirring martial appeals that recall their ancestors' impossible war against Great Britain. Although the "old Hero" refers to Harrison, the allusion (made by Harrison's moniker and military rank) is to the country's first general, George Washington. The memory of the latter, set in the language of regenerative war against the "corrupt practices" of President Van Buren's "rotten administration,” work to justify Stuart's oppositional zeal.

The oppositional dimension to the role of mid-level commander was complemented by appeals to martial unity, which, having been drawn from the older antiparty strains of revolutionary republicanism, expressed impatience with dissension in the ranks. During the struggle between Martin Van Buren and Lewis Cass for the 1844 Democratic presidential nomination, which eventuated in the compromise candidacy of James K. Polk, Wentworth commanded his colleagues to "cease your battles for a while among yourselves and turn your cannon upon the common foe, as every blow you strike against yourselves is so much in aid of the federal party." (Chicago Democrat, 7 February 1844) Instead of making a straightforward appeal to party unity, Wentworth exploits the evocative imagery of cannon fire to convey the urgency of their predicament, adding that "every blow you strike against yourselves" merely advanced the cause of "the federal party." That the Democrat uses the memory of federalism here in place of Whiggism bears mention, as well, for the former comprised in Democratic circles the 
traitorous faction that emerged immediately after the revolution without warning.

Of course, Wentworth was not always so reasonable. Late in the 1844 campaign season, in an editorial printed some eight months after the preceding passage, he warned, "Any man elected on the democratic ticket who will go for any kind of a bank or for the resuscitation of the old ones will commit a fraud on his party and will receive the traitor's reward." (Chicago Democrat, 9 October 1844) Recalling the repressive impulse of Washington and Hamilton before him, Wentworth assumes the prerogative of the military commander to mete out to his troops the "traitor's reward," which was nothing less than a death sentence. The phrase is an allusion to the term "decapitation," which, in antebellum political circles, meant to be removed from one's position in the party. Those who broke ranks after the election, in other words, would find themselves without the party's nomination in the next election cycle.

Martial discourse therefore helped to stabilize party politics among local elites by providing a framework within which they could carve out an identity for themselves in the emerging mass party system. Some editors self-consciously viewed themselves as the press and likened their role in the party to that of guardians or sentinels. Others embraced the role of a mid-level commander who both united the local party and led them into political battle.

\section{Social Change on the Ground}

Martial discourse also allowed voters a way to participate in elective politics as the foot soldiers of their respective parties. In this, electoral parades provide a crucial data source. We begin with examples from outside Illinois and Alabama to give a sense of the nationwide acceptance of martial practices among voters. In Tennessee, grassroots Whig activists, called "Bell Guards," were said to number around 10,000, and the voters and precinct captains of both parties were reportedly "organized into uniform companies and regularly drilled." According to the same report, 17,000 people joined a recent procession, while an estimated 60,000 to 70,000 looked on. (Chicago American, 2 September 1844) Similarly, in the District of Columbia, the Independent Monitor reported, "Young Men formed a procession, and with their banners and emblems raised on high, marched in fine order through the principal avenues of the city." (Independent Monitor, 20 March 20 1840) Martial discourse therefore manifested itself on the ground in the literal regimentation of the mass electorate. Voters enthusiastically embraced the military aesthetic, plugging themselves into the political process as the infantrymen of the respective parties. Figure 1 is an artist's depiction of a Whig procession during the 1840 presidential campaign. The piece reveals all the trappings of an antebellum professional army, including flags, weapons, the fife and drum, horses, and uniformed horsemen and marchers, offering voters any number of "positions" to take up in the course of just one political event. Note, too, that party headquarters were located not at a church, city hall, or other civilian building, but at "Northern Military Hall" where the candidate, General William Henry Harrison, is pictured on his horse as the leader of the army and party and the people's standard-bearer. ${ }^{58}$

Tuscaloosa had its share of martial processions. In the editorial below, the Whig Monitor chides the Democrats for complaining about a local parade for Harrison during the 1840 presidential campaign. The parade of the Whig ranks is clearly martial in character, as this passage suggests:

\begin{abstract}
How the Democrats of Tuscaloosa wail and deplore the Whig spirit which could so far leap over all decency in the late procession in this city, as to induce one of the Marshals of the day to carry holsters at his saddle bow. Come, ye civil and peace-loving Democrats, do not be frightened at this display of the trappings of war ... The "holsters" which you have thought proper to embody in your address, were only part of a saddle covering intended for military occasions, and had no pistols in them-not even were they surcharged. (Independent Monitor, 12 June 1840)
\end{abstract}

The significance of this editorial is two-fold. First, if by 1840 it had become a common practice for the rank-and-file to "drill" during the course of the campaign season, then the Whig ranks had become so enthusiastic in their embrace of the martial form that they were now displaying "holsters" and other "trappings of war," much to the dismay of even the Democrats. Second, that this argument over the proper conduct of political parades took place in Tuscaloosa, Alabama suggests, with the foregoing example from Tennessee, that the martial mobilization of voters had now reached the capital cities of the western states and thus were likely in operation even in the capillary locales of the body politic.

What seemed to animate this enthusiasm for the martial form was a sense of kinship with the original revolutionary patriots. When the Democrats celebrated their victory in the 1844 presidential election at a martial procession in Washington, DC, the Illinois rank-and-file delegation, which was said to include a contingent of "day laborers," carried a banner that was described as follows: ${ }^{59}$

58. Lamont Buchanan, Ballot for Americans: a pictorial history of American elections and electioneering with the top political personalities, 1789-1956 (New York: Dutton, 1956), 26.

59 . For the use of banners as a data source for subaltern subjectivity, see Sean Wilentz, Chants Democratic: New York City and the Rise of the American Working Class, 1788-1850 (New York: Oxford University Press, 1984). 


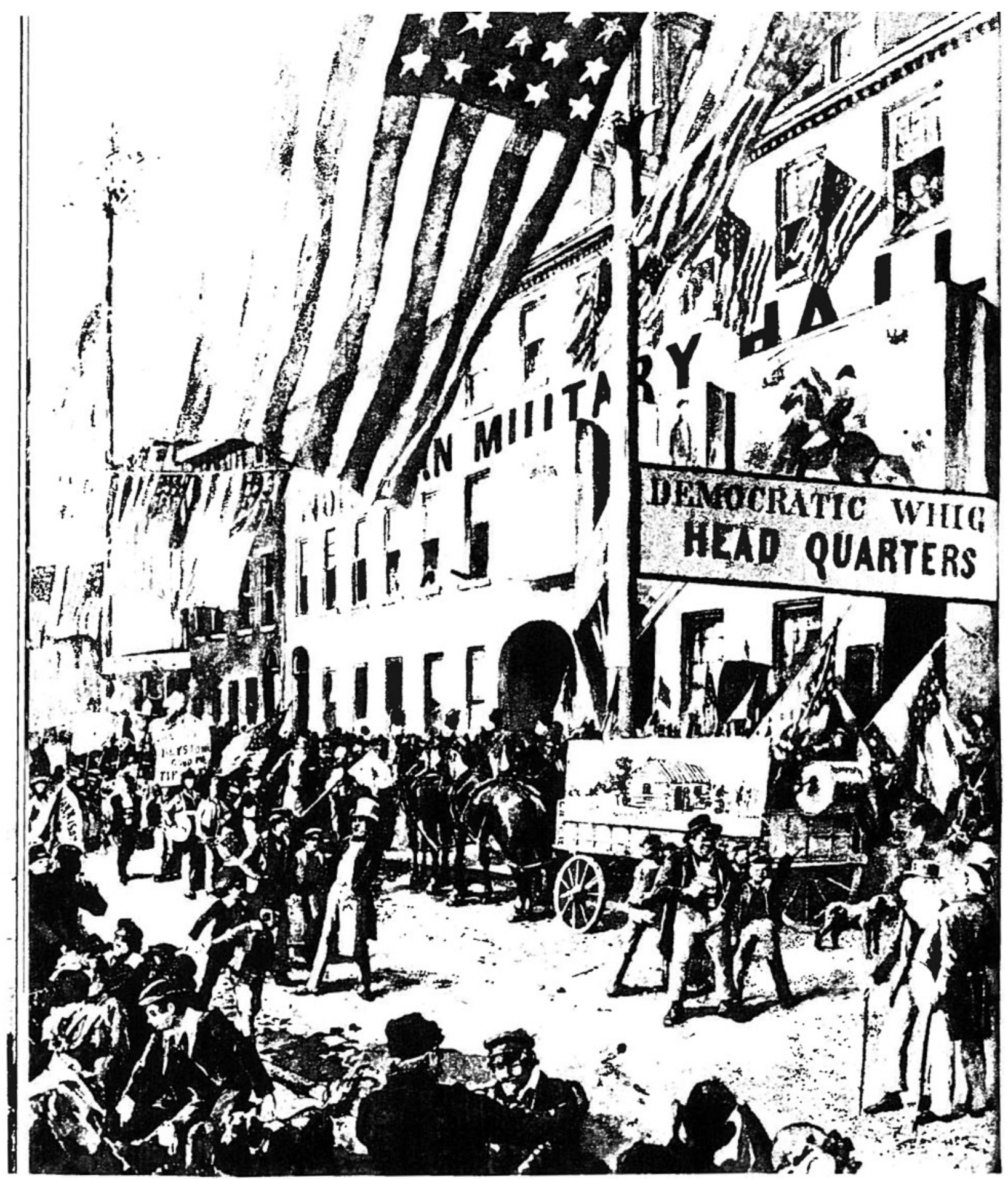

Fig. 1. Whig Procession, 1840.

Col. Ezekiel Polk, mounted as an officer in the revolutionary army. Motto: "He dispersed the tories in the snow campaign of ' 76 ; his grandson will scatter them in the fall campaign of '44." Reverse motto: "Infamy to the catiff slanderers of the departed patriot hero of the revolution. (Chicago Democrat, 25 December 1844)
The banner tells of President-elect Polk's grandfather, a veteran of the revolutionary war who was allegedly slandered in the course of the election campaign. The text is a classic martial reference to the American Revolution, in which a direct line is drawn from the revolutionary generation's military conquests to the 
second generation's conquests on the field of political battle. More importantly for our purposes, the rank-and-file appear to have internalized the binary logic of martial discourse. They view themselves as soldiers in this new political army, commanded by Ezekiel Polk's grandson, and view their counterparts in the Whig Party as the descendants of the "tories in the snow campaign of '76."

Martial discourse therefore provided voters with a language for participating in, and celebrating, their activism on behalf of the political parties. A rank-and-file Chicago Democrat named John Moore, for instance, wrote this letter to the editor, describing his plans for handling the Whigs in the upcoming presidential election: "The whigs of this district are already beginning to rally their scattered forces for the coming contest; but we will again meet the enemy and make them ours." (Chicago Democrat, 20 March 1844) The author proudly promises to deliver the votes of his district to the Democratic Party, and does so by using the rhetorical tools of local and national party elites. In a single sentence, he, too, manages to repeat the binary logic of martial discourse. Moore conveys a kind of wartime urgency by announcing that the Whigs have begun to "rally their scattered forces" and then states his and his fellow Democrats' determination to "meet the enemy and make them ours."

The sentiments of Tuscaloosa Democrats were no different at this time. At a local meeting, Democratic voters vowed to maintain martial unity for the remainder of the 1844 presidential campaign: "Resolved, ... we pledge ourselves to enter into the coming canvass as a band of brothers, bound together by the ties of principle, and animated by the confident hope of obtaining glorious victory." (Democratic Gazette, 13 June 1844) In this passage, the Democratic ranks articulate their mission in the coming months, not in organizational, but in martial terms. They pledge to be soldiers like the original "band of brothers," a reference to the martial unity of the revolutionary patriots, and to march toward "glorious victory," a common rhetorical phrase for equating electoral success with military renown.

The capacity of the martial form to provide voters with a way to participate actively in elective politics contributed to party stabilization on the ground, a finding that is reflected in the rise in voter turnout for the major party candidates after 1824 when martial rhetoric and the theoretical strands of partyist discourse became entrenched. Table 1 compares voter turnout for the 1824 and 1844 presidential elections in Alabama, Illinois, and Tuscaloosa's and Chicago's home counties. Recall that the 1824 contest was notable for its lack of party discipline, with the five personal factions of the Monroe years each putting up their own candidate. In 1844, turnout in Alabama rose 26 points or by about half the 1824 figure. In Tuscaloosa, turnout increased by 80
Table 1. State and County Level Estimated Voter Turnout for the 1824 and 1844 Presidential Elections

\begin{tabular}{lcc}
\hline Region & $\begin{array}{c}\text { Estimated voter } \\
\text { turnout, 1824 }(\%)\end{array}$ & $\begin{array}{c}\text { Estimated voter } \\
\text { turnout, 1844 }(\%)\end{array}$ \\
\hline Alabama & 57.83 & 83.62 \\
Illinois & 30.65 & 95.61 \\
Tuscaloosa & 47.67 & 85.44 \\
$\quad$ County & & \\
Clark/Cook & 8.30 & 92.00 \\
$\quad$ County & & \\
\hline
\end{tabular}

percent. The effect of mass party discipline was even more marked in Illinois, where turnout tripled statewide and went from virtually nil to an astonishing 92 percent in Chicago's home county. ${ }^{60}$

\section{CONCLUSION}

At all levels of the body politic, then, from nationally prominent elites to local party editors and voters on the ground, martial discourse aided in the recruitment of different sets of actors into the practice of mass partisanship. After the 1824 presidential election, previously antiparty national elites accepted the need for mass party discipline and indeed tried to convince others of that need, using military imagery. At the local level, martial discourse provided a logic within which Chicago and Tuscaloosa elites could see themselves as sentinels or mid-level military

60. The 1824 electoral returns for Illinois and Clark County were retrieved from Tufts University Digital Collection and Archives, "A New Nation Votes: American Election Returns 17871825,” http://elections.lib.tufts.edu/aas_portal/index.xq (accessed 9 Jan. 2009). Note that in 1820, Chicago was part of Clark County. Cook County was organized in 1831. The 1824 electoral returns for Alabama and Tuscaloosa County are from the Alabama Secretary of State, "Election files - state and national, 1823-ongoing," (Montgomery, AL: Office of the Secretary of State, State of Alabama, 1823-ongoing), housed at the Alabama Department of Archives and History in Montgomery. The 1844 electoral returns for Illinois and Cook County are from the Interuniversity Consortium for Political and Social Research, UNITED STATES HISTORICAL ELECTION RETURNS, 1824-1968 [Computer file], Study 1 Part 0057: Election Returns for Illinois, 18241878 (Ann Arbor, MI: Inter-university Consortium for Political and Social Research, 1999). For the 1844 electoral returns for Alabama and Tuscaloosa County, see the Tuscaloosa Democratic Gazette 28 Nov. 1844. The voting age white male population was extrapolated from U.S. Census data in ICPSR Study 3 by subtracting the number of free white males under 20 years of age from the total number of free white males. Inter-university Consortium for Political and Social Research, HISTORICAL, DEMOGRAPHIC, ECONOMIC, AND SOCIAL DATA: THE UNITED STATES, 1790-1970 [Computer file], Study 3 (Ann Arbor, MI: Inter-university Consortium for Political and Social Research, 197?). It should be noted that while the voting age in this period was 21 , the number of 20-year-old free white men is likely to have been offset by the increase in population in the four years between the decennial census and the election in each case. 
commanders. Finally, the data suggest that martial discourse offered voters a way to participate actively in elective politics, an opportunity that they embraced partly because of an imagined affinity with the original foot soldiers of the revolution.

Historians of party formation emphasize the formal and legalistic aspects of the theory of party. In contrast, this account highlights the role of a no less pervasive, but perhaps more pedestrian, rhetoric in overcoming the antipartyism of the early national electorate. In doing so, my goal has not been to supplant existing accounts of the transition to mass party competition, but rather to integrate a relatively neglected chapter into the story that already exists on the subject. Specifically, I have attempted to synthesize the literatures on martial discourse and antipartyism by combining the insights of Kruman and Leonard respectively. The resulting claim is that the mass appeal of military language and thus its role in stabilizing partisan conflict is linked to its impatience for division in the patriot ranks and its call to arms against the remnants of British aristocracy. Martial discourse therefore offered something to secondgeneration politicians, operatives, and voters that the more scholarly threads of party discourse did not, namely, the opportunity to "fight" in a revolution they had missed. Accordingly, I have defined "recruitment" not in stark causal terms, but as an unfolding process of recognition, in which otherwise isolated social groups came to recognize their complementary roles in the incipient mass party apparatus through the lens of revolutionary wartime discipline.

Moreover, the process of recognition sheds light on the mobilizing practices of early mass parties without wading into the debate over which social cleavage constituted the principal cleavage of the Jacksonian
Era. We have seen how the Democrats fused martial discourse with the banking issue to interpellate voters as class actors, but martial discourse was also used to mobilize voters along the ethnocultural lines privileged by Lee Benson and Ronald Formisano. In response to Whig attempts to disfranchise immigrants, German rank-and-file Democrats hoisted this banner at the aforementioned victory parade for President-elect Polk: "De Kalb, the German hero of the revolution must be protected in the land for whose liberties he fought and died ... Remember the war cry of the whigs, when feloniously robbing on the highway to the polls the German citizen of his rights: 'Another damned black Dutchman-knock him down-beat out his brains."” (Chicago Democrat, 25 December 1844) Thus, it was partly within the martial framework that German voters came to recognize themselves as both Democrats and Americans, the true successors to DeKalb and the patriot cause. Furthermore, in their exhortation to other Germans to "remember" the xenophobic "war cry" of the Whigs, they reveal their intention to recruit still other Germans to the Democratic Party. ${ }^{61}$

Finally, this paper has something to say about political parties and democracy. It puts party elites and political discourse at the center of democratic transitions and expansions, thus revising the widely held assumption that social classes are the prime movers of democratization. In doing so, the paper also enriches elite-driven accounts of electoral competition, like those of Aldrich, Shefter, and the literature on officeseeking and political ambition, by adding a complex cultural dimension to what elites must do, first to justify the existence of parties if necessary, and then to use salient discursive tropes to win. ${ }^{62}$
61. Lee Benson, The Concept of Jacksonian Democracy: New York as a Test Case (Princeton: Princeton University Press, 1961), 27; Formisano, The Birth of Mass Political Parties, 55. On the class side of the debate, see for instance, J. Mills Thornton III, Politics and Power in a Slave Society: Alabama, 1800-1860 (Baton Rouge: Louisiana State University Press, 1978); John Ashworth, 'Agrarians' Eे 'Aristocrats': Party Political Ideology in the United States, 1837-1846 (London: Royal Historical Society; Atlantic Highlands, NJ: Humanities Press, 1983); Charles G. Sellers, The Market Revolution: Jacksonian American, 1815-1846 (New York: Oxford University Press, 1991).

62. Aldrich, Why Parties?; Martin Shefter, Political Parties and the State, Joseph A. Schlesinger, Ambition and Politics: Political Careers in the United States (Chicago: Rand McNally, 1966); Joseph A. Schlesinger, Political Parties and the Winning of Office (Ann Arbor: University of Michigan Press, 1991). 